\title{
Analyze Production, Utilization and Its Future Trends of Lupin in Ethiopia
}

\author{
Akale Assamere Habtemariam, Alemu Mamuye Woldetsadik, Asmamaw Menelih Belay \\ Department of Biology, Faculty of Natural Science, Mekdela Amba University, Tuluawlia, Ethiopia \\ Email: akale1819@gmail.com, alemayehu.mamuye@yahoo.com, asmamaw2astu.et@gmail.com
}

How to cite this paper: Habtemariam, A.A., Woldetsadik, A.M. and Belay, A.M. (2019) Analyze Production, Utilization and Its Future Trends of Lupin in Ethiopia. American Journal of Plant Sciences, 10, 1797-1812.

https://doi.org/10.4236/ajps.2019.1010127

Received: August 30, 2019

Accepted: October 20, 2019

Published: October 23, 2019

Copyright () 2019 by author(s) and Scientific Research Publishing Inc. This work is licensed under the Creative Commons Attribution International License (CC BY 4.0).

http://creativecommons.org/licenses/by/4.0/

\begin{abstract}
Lupin is a significant legume crops to maintain the sustainable farming practice. It is important to analyze production and utilization trends to forecast future trends and create good insights. The CSA published data, recorded in 2001/02 until 2017/18 cropping seasons, were used for analysis using Excel and SPSS version 21. Inconsistent trends of Lupin productions were recorded in Ethiopia, South Africa and Egypt, but increasing in Morocco. In Ethiopia, the productions were ranged between 48,326 and 443,705.05 quintals. All the recorded yields were ranged between 3.22 and $16.65 \mathrm{q} / \mathrm{ha}$ and declined in 2009/10-2012/13 and increased trends in 2015/16-2017/18 cropping seasons. In Ethiopia, about $95.85 \%$ of land coverage and $99.29 \%$ of total productions accounted from Amhara region in 2017/18 cropping season and Benishangul Gumz region is the second producers. West Gojam and Awi zone are the first and the second, which accounted major productions in the country. Out of the total production, $44.61 \%, 53.28 \%$ and $50.48 \%$ in $2009 / 10,2011 / 12$ and 2017/18 were utilized as sales respectively. The major Lupin production, in 2009/10 (Amhara and Benishangul Gumz), 2010/11 (Benishangul Gumz and Oromia) and 2011/12 (Southern Nation Nationalities and Peoples Regional state), were utilized as household consumption. In Amhara region, the majority of the productions were utilized for sales in 2009/10, 2011/12 and 2017/18 cropping seasons. This indicated that the percentage of utilization showed inconsistent trends and mostly used as sales. In Ethiopia, inconsistent trends of Lupin will be continued in the next four years.
\end{abstract}

\section{Keywords}

Land Coverage, Lupin, Production, Utilization, Yield

\section{Introduction}

Lupin is characterized by wide range of varieties with about 300 different species 
[1]. Of these, only four of $L$. albus (white lupin), L. angustifolius (blue lupin), $L$. luteus (yellow lupin) and L. mutabilis (Pearl lupin) gained agricultural importance [2]. It is cultivated around the Mediterranean and in the Nile valley, extending to Sudan, Ethiopia as well as some parts of Southeastern and Southern Africa [3].

Australia is the largest producer of lupine in the world, followed by Europe [4]. Similarly, the crop is produced in different parts of Ethiopia; particularly in two regional states; Amhara and Benishangul Gumuz, the former being the largest producer [3] [4]. It is mostly cultivating in West Gojjam and Awi zones of Amhara. The Ethiopian lupine cultivation, genetic improvement and utilization remain far behind the other pulse crops [5]. In Ethiopian farming system, white lupin is producing as a sole or intercropping with other crops [2]. However, the annual coverage, production and yields showed inconsistent trends.

Lupins are important legume crops that form a critical part of sustainable farming systems [6]. Globally, it is used for livestock, poultry feed and fertilizing the soil [4]. It's nature of adaptation to wide range of climates also making it an attractive crop [4]. Lupin is relatively more tolerant to several abiotic stresses than other legumes, and has a high potential for the recovery of poor and polluted soils [7]. Beside to this, it is effective in raising soil fertility via symbiotic nitrogen fixation and mobilization of soil phosphorus [8].

Lupin plays a great role in keeping human health by providing proteins, fats and carbohydrates. It is also serving as a source of different food items and food additives [6]. Its flour can be added to pasta, crisps, bread and emulsified meat products to increase nutritional value, aroma as well as modify the texture of the products. It is known as "Gibto" in Ethiopia, which is used as roasted bean "ko$l o$ " and to prepare local alcoholic drink "katikala", and other food products [9]. The seeds are rich in protein, ranging from $30 \%$ to $40 \%$ of whole seeds [6]. It is often used in the bakery industry, especially in European countries for the last few years [4]. Similarly, the majority of the production is utilized for sales. This indicated that the household utilization is not accustomed in case of Ethiopia. Therefore, it is vital to analyze the production and utilization trends in the zonal, regional and country level.

\section{Methodology}

\subsection{Coverage of the Survey}

Secondary data of Annual Agricultural Sample Survey were used from CSA published data of Ethiopia ranged from 2001/02 until 2017/18 cropping seasons [10]-[22]. The CSA recorded all the crops data throughout the year; however, the analyses were not extracting the specific crops. Therefore, Lupin coverage, production and productivity were selected out via cross-cheeked system from the many cereal and pulse crops, which were recorded in different seasonal cropping published by CSA [10]-[22].

All recorded data of CSA collected from lupin producing regions of the coun- 
try was analyzed to determine the trends of Lupin area coverage, production and yields (Figure 1).

\subsection{Selections of Lupin}

In Ethiopia, Lupin are underutilized crops, however it play a key role to treat malnutrition. Lupins have twice as much protein as beans, chickpeas, lentils and other legumes [23]. However, the land coverage, production and yield status showed high fluctuation trends. Therefore, this analyzed concern on the underutilized legume crops.

\subsection{Model Selection}

Forecasting of area and production using the best fitted methods, were Extracted via generated the data and building ARIMA models to predict the future values. Therefore, ARIMA and Simple model were used to analyze the given data [24].

\subsection{Data Analysis}

The data were analyzed through descriptive statistical analysis, excel and SPSS version 21 . The data is presented using figures [25].

\section{Results and Discussion}

The total production record of 14 years data indicated that inconsistent trends of increasing and decreasing of total harvested coverage (ha), production (q) and yield (q/ha) of Lupin in Ethiopia, South Africa and Egypt, but increasing in Morocco. As confirmed [1] stated that high genetic diversity of White Lupin landraces were observed in Ethiopia, Egypt, Morocco and Spain, through ISSR, AFLP, SSR and DArT marker. In Morocco, different samples of Lupin were collected to evaluate and identify the best lines [26]. This breeding technology was the result that has been maximizing and sustaining the productivities of it in Morocco. Likewise, yields of Lupin showed upward trends in South Africa from 2010/11-2017/18 harvesting years. Yield (q/ha) was high in Egypt, but it showed inconsistent trend. Comparatively, the production and yields of Lupin in Ethiopia showed a high degree of fluctuation (Figure 2 and Figure 3 ). The low production and yields might be the lack of sustainable agronomic practice in the country.

In Ethiopia, the productions were recorded between the range of 48,326 and 443,705.05 quintals in 2003/04 and 2011/12 cropping seasons respectively (Figure 4). All the recorded yields were ranged between 3.22 and $16.65 \mathrm{q} / \mathrm{ha}$ in 2003/04 and 2009/10 cropping seasons respectively (Figure 5). It showed declined trends in 2009/10-2012/13 and increased in 2015/16-2017/18 cropping seasons. This some increment of yields might be the released of some improved varieties in Achefere (West Gojjam) with the help of Andassa Agricultural Research Center. At regional level, the overall trends of Lupin production also observed high degree of fluctuations (Figure 4 and Figure 5). Also [2] showed 
similar results in the country. This indicates that the crop gained less attention by the government, lack of well-known improved varieties, and lack of aware farmers might be the cause of its decline. The case of Lupin production problems in Ethiopian also showed in Europe, which was declined steadily during the second half of the 20th century, mainly because of low productivity driven by seasonal variability, the low price of lupin grain, and EU policies favoring the importation of soya bean [7]. A similar result in Ethiopia was confirmed [27], due to less disease resistant, high alkaloids contents, low desirable and bitter varieties.

These results revealed that Amhara and Benishangul Gumz regions were a major lupin producer and the former is the leading, which accounted the largest production in the country. As the graph (Figure 6 and Figure 7) showed that the overall trends of Lupin were inconsistent in both regions of Ethiopia. In

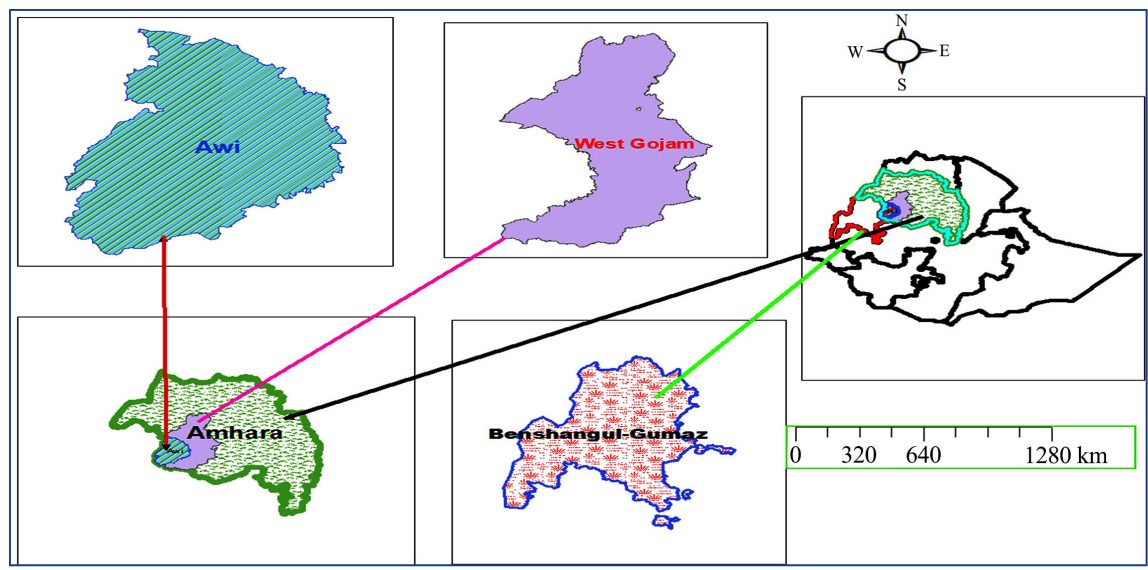

Figure 1. A major Lupin producer regions and zones of Ethiopia.

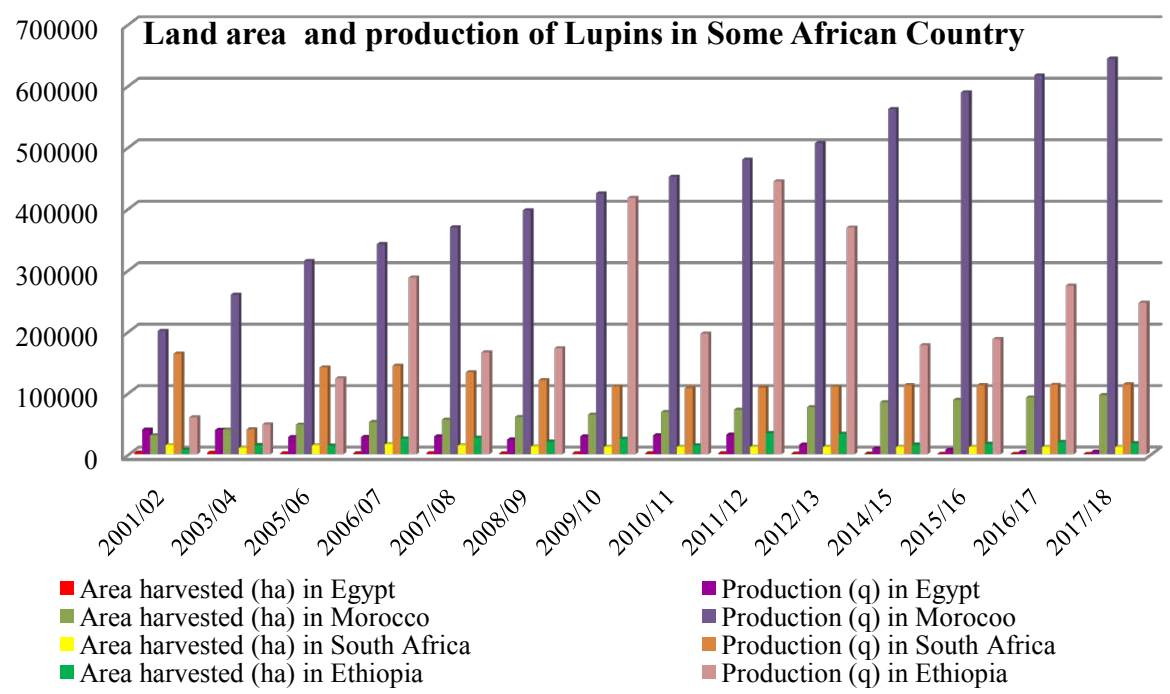

Figure 2. Trends of land coverage (ha) and its production (q) of lupin in Four African countries. 


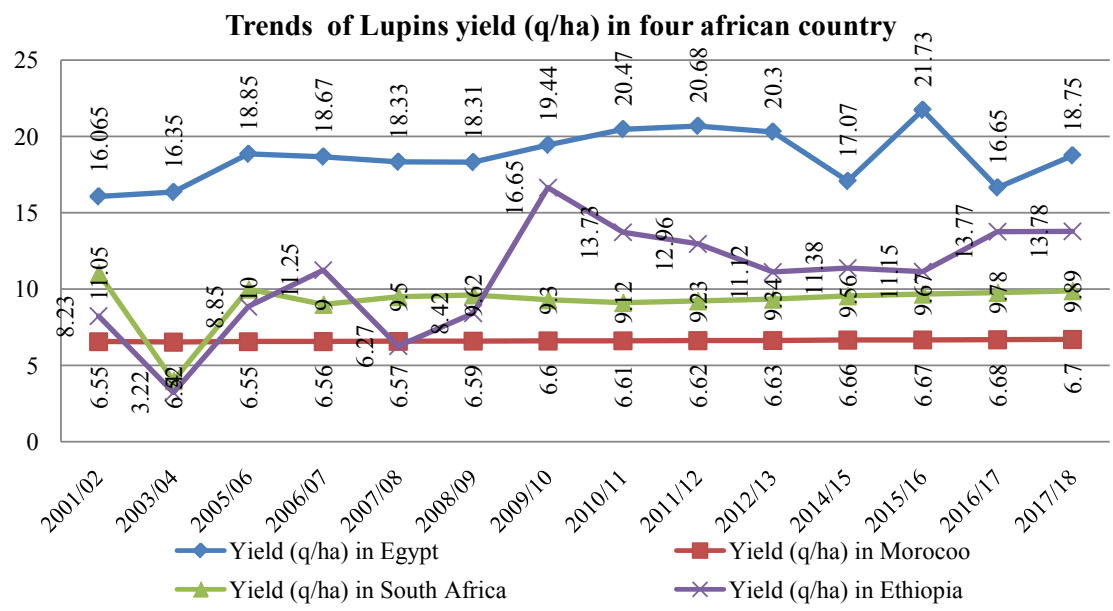

Figure 3. Trends of lupin yields ( $\mathrm{q} / \mathrm{ha}$ ) in the four African countries.

\section{Land area and production of Lupins in Ethiopia : 2001/02- 2017/18 cropping seasons}

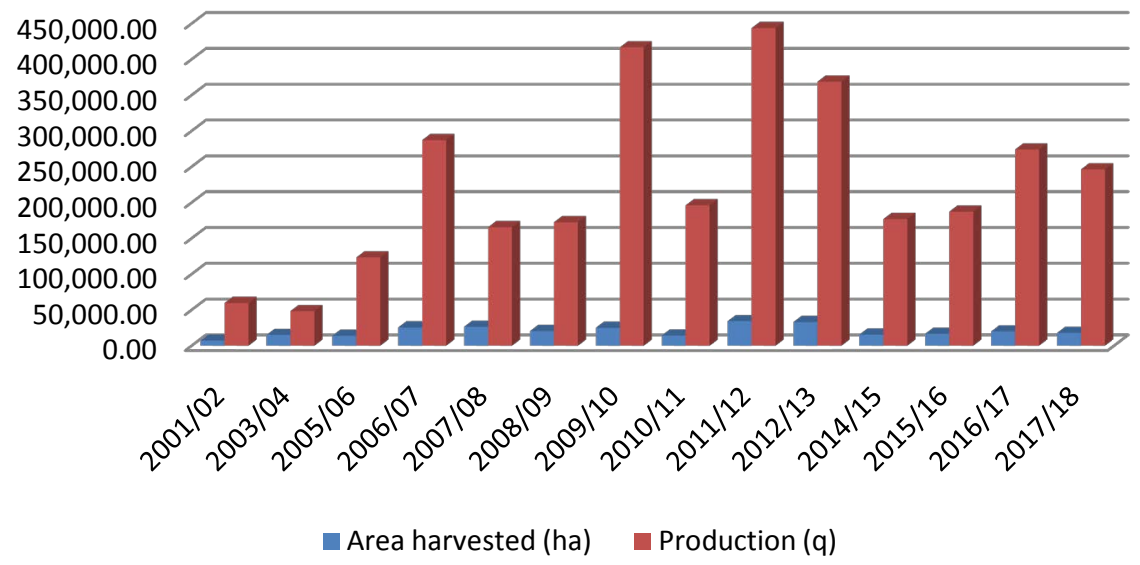

Figure 4. Trends of land coverage and production (q) of Lupin in Ethiopia.

Trends of Lupins yield (q/ha) in Ethiopia; in 2001/02-2017/18 cropping seasons
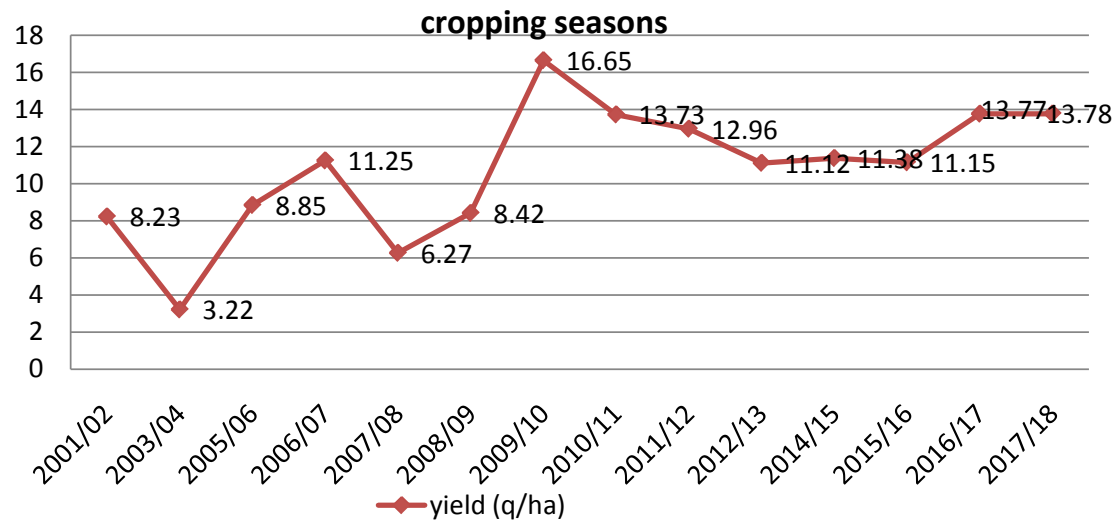

Figure 5. Trends of Lupin yields (q/ha) in Ethiopia. 


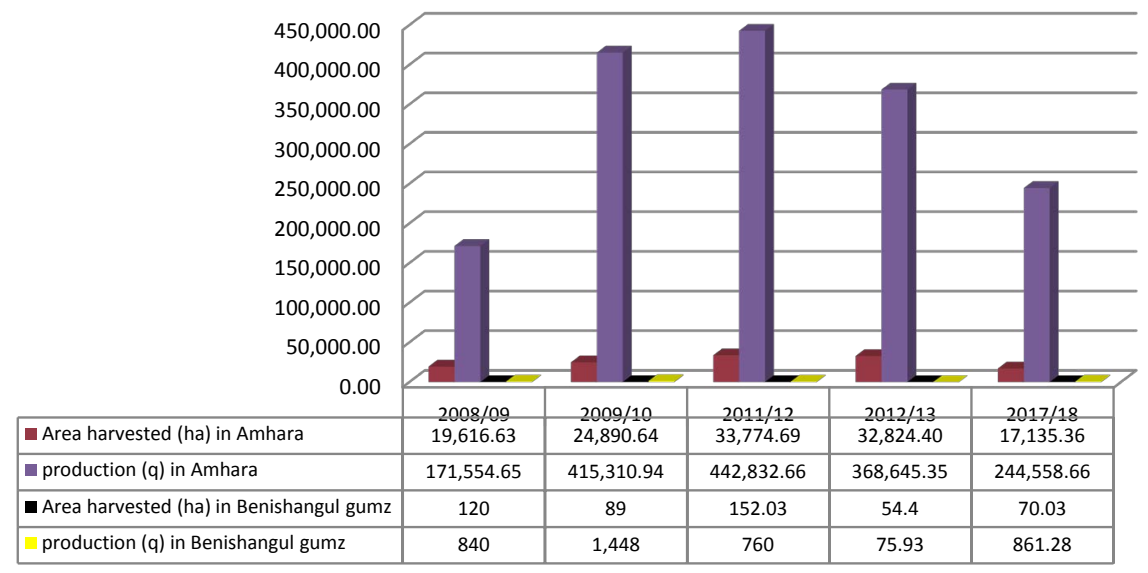

Figure 6. Trends of land coverage and production of Lupin in Amhara and Benishangul gumz.

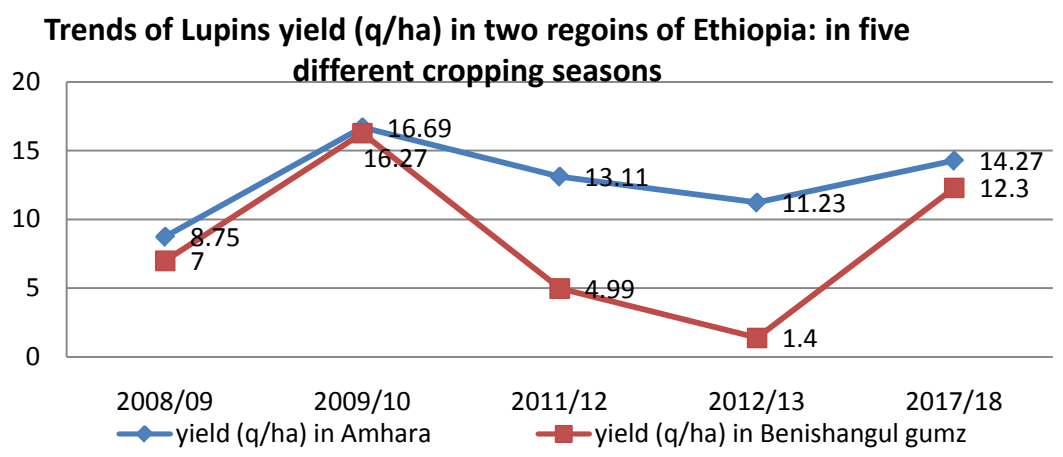

Figure 7. Trends of Lupin yields ( $\mathrm{q} / \mathrm{ha}$ ) in Amhara and Benishangul gumz regions.

Ethiopia, about $95.85 \%$ of land coverage and $99.29 \%$ of total productions were accounted in Amhara region during 2017/18 cropping season and Benishangul gumz region is the second producers. [5] supported these results and stated Amhara region comprised higher genetic diversity of white lupine than Benishangul Gumuz region. The maximum production was also recorded in Amhara region during 2011/12 cropping season.

\subsection{Major Area, Production and Productivity of Lupin in Amhara Region}

West Gojjam and Awi zones were the major Lupin producer, which covered major productions in the country. The former was the leading and the later was the second producer in the region. However, the land coverage, production and yields showed decreasing and increasing in year to year in the two zones (Figure 8 and Figure 9). [28] reported that low population differentiation of White Lupin were observed in West Gojam, Awi, East Gojam and Gondar of Ethiopia, but showed greatest genetic distance of Lupin population that were collected from Australian. [27] reported that high yields were recorded from narrow-leafed lupin (Lupinus angustifolius L.) than White Lupin which were harvested in Mera- 
wi and Finoteselam in the mid altitude of 2095 and 1935 m.a.s.l respectively and Kossober 1 and Kossober 2 in the high-altitude (relatively cold) of 2610 m.a.s.l. Similarly, Result by [8] supported that improved sweet lupin seed were recorded only at South Achefer (West Gojam) district due to interventions of Andassa Agricultural Research Center, but not in Machakel, Sekela (East Gojam) and Dera (South Gondar) districts due to lack of inputs and awareness.

\subsection{Lupin Commercialization and Utilization}

In Ethiopia, the major production $44.61 \%$ of $416,759.00$ quintals (2009/10), $53.28 \%$ of $443,705.05$ quintals $(2011 / 12)$ and $50.48 \%$ of $246,294.20$ quintals (2017/18) were utilized for sales (Figure 10). This result was confirmed to [8] and stated that consumption of lupin at the farm household level is limited (35\%) due to a social taboo that says, "Lupin is for the poor and it is unsuitable nutrition". Therefore, farmers were not aware about the utilization customs the plant as a household consumption. As shown below Figure 10, the percentage of utilizations similarly showed some inconsistent trends like production and yields.

In Amhara, Benishangul Gumz, Oromia and SNNPR, 46.2\%, 55.83\% and $64.67 \%, 67.5 \%$, and $67.86 \%$ of the total productions were utilized as household consumption respectively (Figure 11). In Amhara region, the majority of the productions were utilized for sales in 2009/10, 2011/12 and 2017/18 cropping seasons. Similarly, [8] reported that most farmers produce lupin for market and very few for livestock fattening at West Amhara Region, Ethiopia. Similarly, the utilization of Lupin in the regional level showed inconsistent trends as shown below (Figure 11).

In East Gojjam, West Gojjam, Awi and Metekel, the majority of the productions were utilized for sales. This indicated that most of the producers could not utilize as a human consumption (Figure 12).

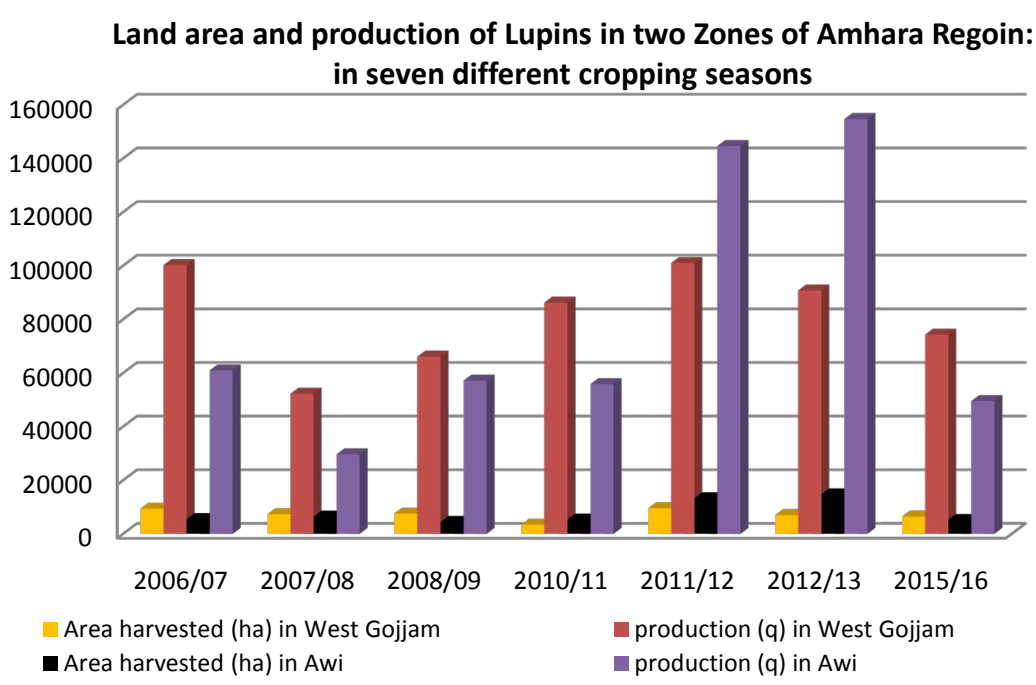

Figure 8. Trends of land coverage and production of Lupin in West Gojjam and Awi zones. 
Trends of Lupins yield (q/ha) in two zones of Amhara region: in seven different cropping seasons

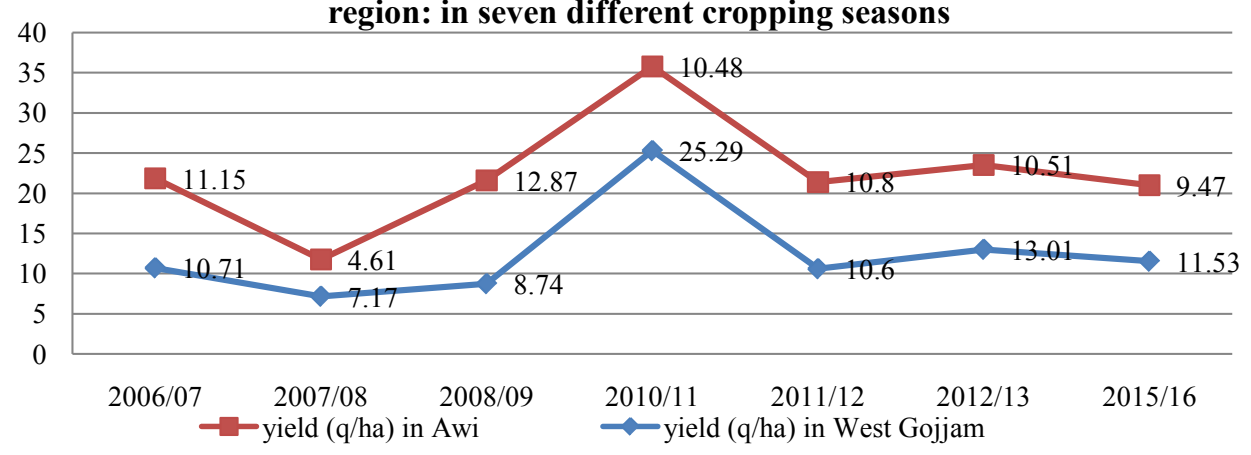

Figure 9. Trends of Lupin yields (q/ha) in West Gojjam and Awi zones of Amhara region.

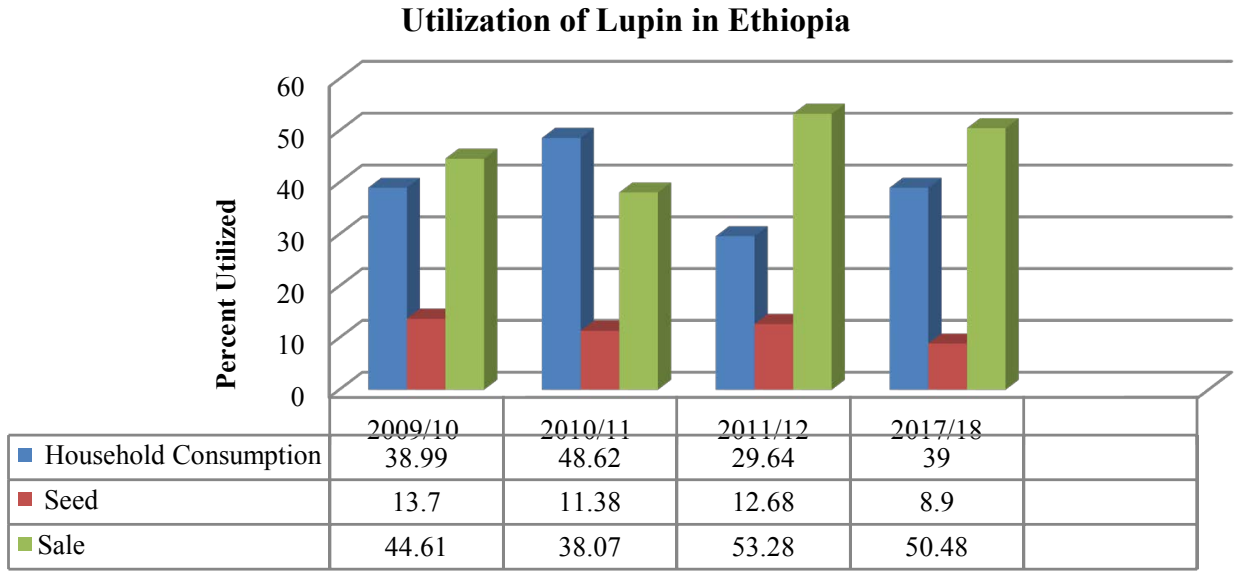

Figure 10. Utilization trends of Lupin in Ethiopia.

Utilization of Lupin in different regions of Ethiopi

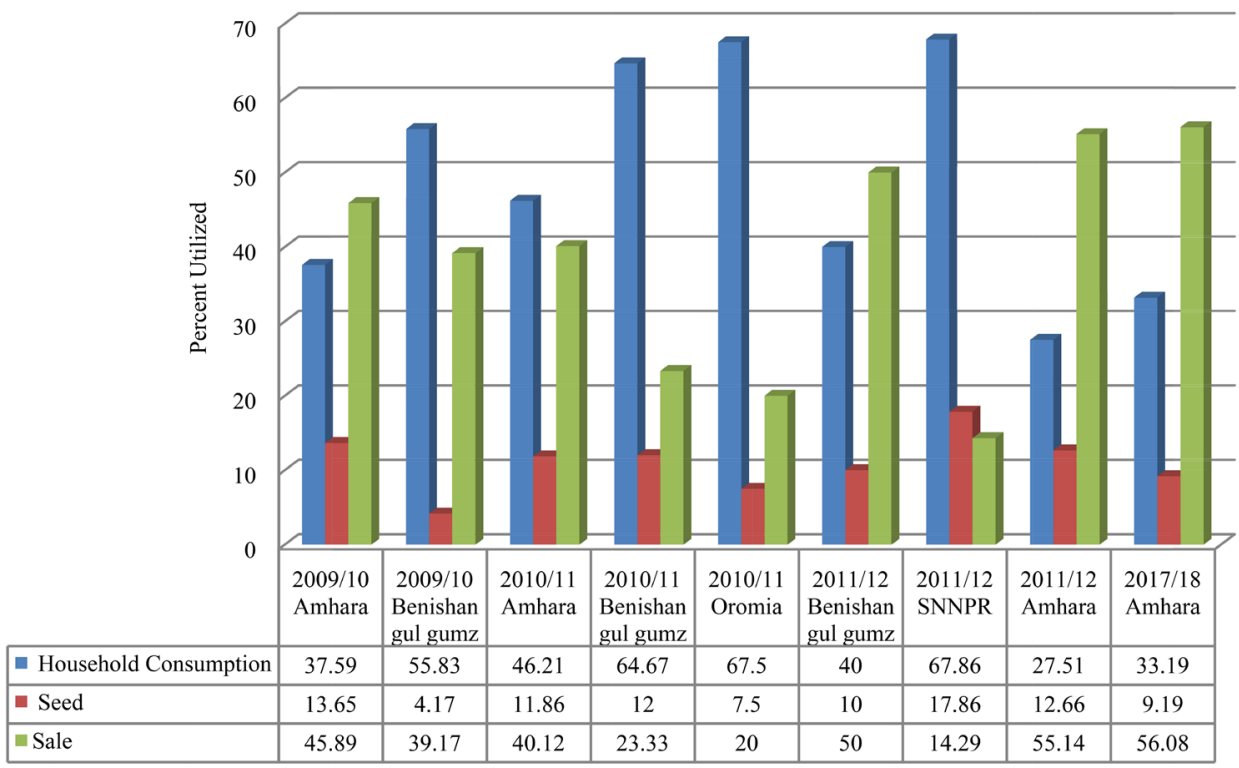

Figure 11. Lupin utilization trends in regional level of Ethiopia. 


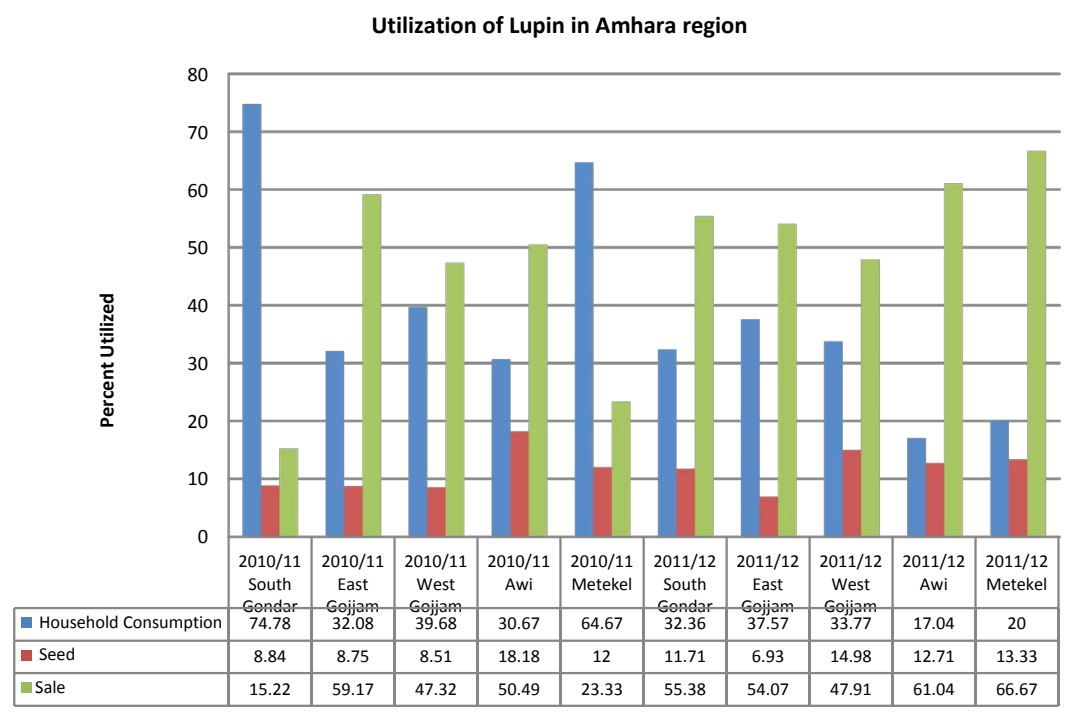

Figure 12. Lupin utilization trends in Amhara region of Ethiopia.

\subsection{Forecasting of Area, Total Production and Productivity of Lupin}

Based on 14 years data, the ARIMA modeling type as shown below (Figure 13) the area coverage and production of Lupin in Morocco is rapid increment in the next four years (2019-2022). This indicated that the government and the Farmers giving prior attention to the production of Lupin. Whereas, the area harvested (ha) and production (q) in Egypt will continue the trends to rapidly decline in the future, as the same manner to the previously. In South Africa and Ethiopia the observed area coverage and production was not good fit to the predicted value and some aspects of the past pattern will be continued in the future. This indicates the government, researcher, agricultural sectors and the farmers itself giving less attention and priority to the other crops. This might be due to the delimitation of breeding technology, awareness of the farmers, the utilization habits of the population in the country.

Total area coverage (ha) and production (q) showed inconsistent trends and the forecasting trend of the next four years (2019(7)-2022(10)) indicated that rapidly decreasing trends particularly in Amhara region (Figure 14). The same results were observed at zonal level, which showed inconsistent trends and might follow similar trends up to 2022 .

\subsection{Constraints of Lupin Production in Ethiopia}

According to [2] reported, minimum agronomic practices such as zero tillage, with no cultivation, and weeding practices make inconsistent production status in Ethiopia. Similarly, the present result showed inconsistent trends of production ( $\mathrm{q}$ ) and yields ( $\mathrm{q} / \mathrm{ha}$ ) of Lupin in the country, regional and zonal level. According to [8], the higher linkage between farmers and extension workers, the more the information flows and the technological (knowledge) transfer from the latter to the former. 
In Ethiopia, availability of desirable varieties was one of the key problems to maintain the sustainability of the production. The local varieties being used by farmers have several undesirable characteristics, such as low yield potential, susceptibility to major diseases and high contents of alkaloids [27]. Lupin generally contains about twice the protein found in those legumes normally consumed by humans [9]. As [27] concluded that sweet narrow-leafed lupin produced the highest forage and grain yield, which were most suitable for the traditional lupin growing area; however, white lupin was sensitive to Fusarium wilt. Therefore, there is a need to develop well-adapted white lupin varieties with farmers' preferred traits including high grain yield, low alkaloids level and resistant to major lupin diseases [28].

\section{Conclusion and Recommendation}

Lupin harvested area, production and productivity show inconsistent trends in some parts of African country including Ethiopia. In Ethiopia, all the recorded yields were ranged between 3.22 and $16.65 \mathrm{q} / \mathrm{ha}$ and it showed declined and increased trends. About $95.85 \%$ of land coverage and $99.29 \%$ of total productions in the country accounted from Amhara region in 2017/18 cropping season and Benishangul Gumz region is the second producers. Most of the productions are limited in Amhara region particularly in west Gojjam and Awi zones. In Amhara region, the major productions were utilized for sales in 2009/10, 2011/12 and

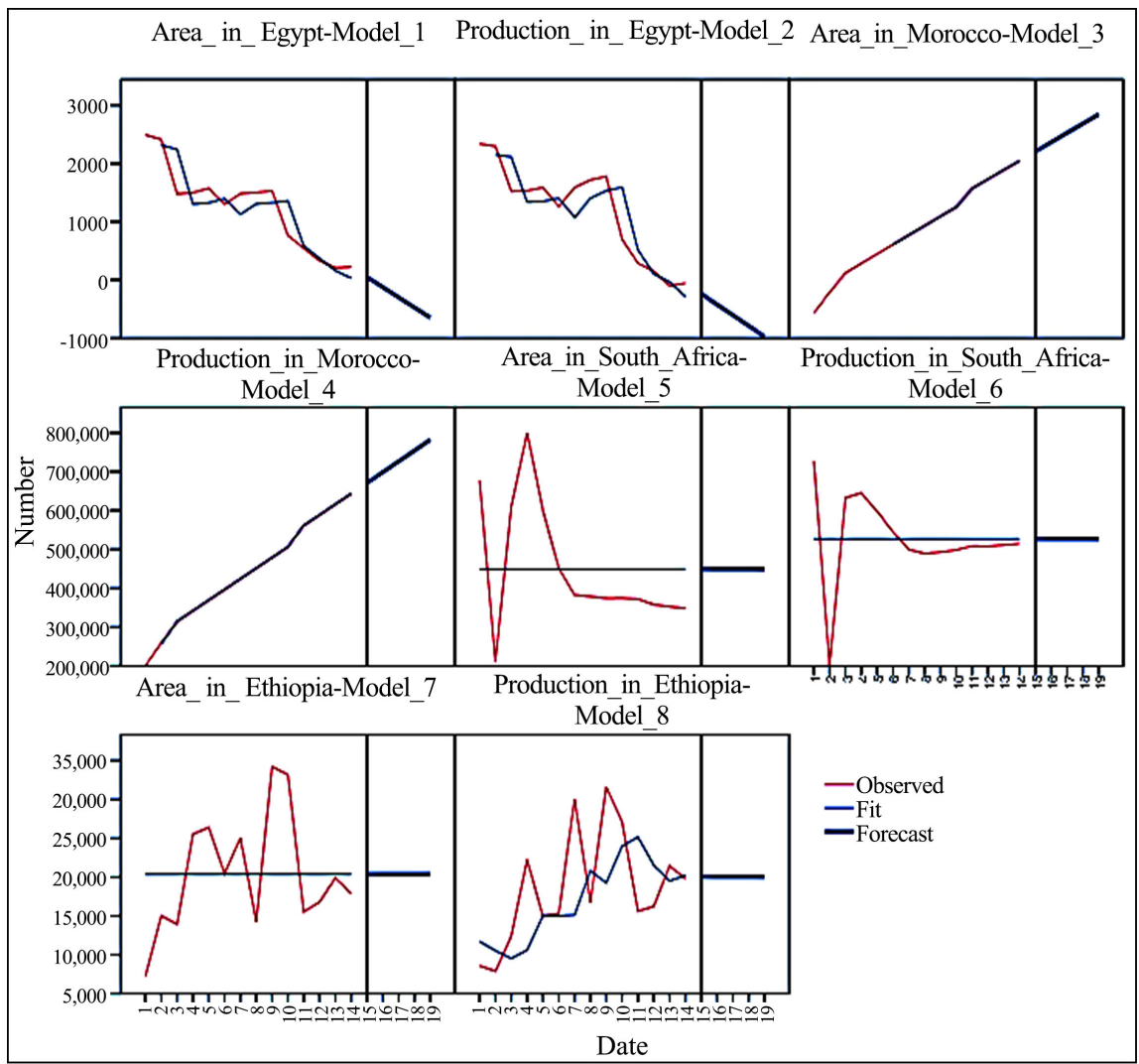

Figure 13. Future trends of Lupin in some parts of African Country. 

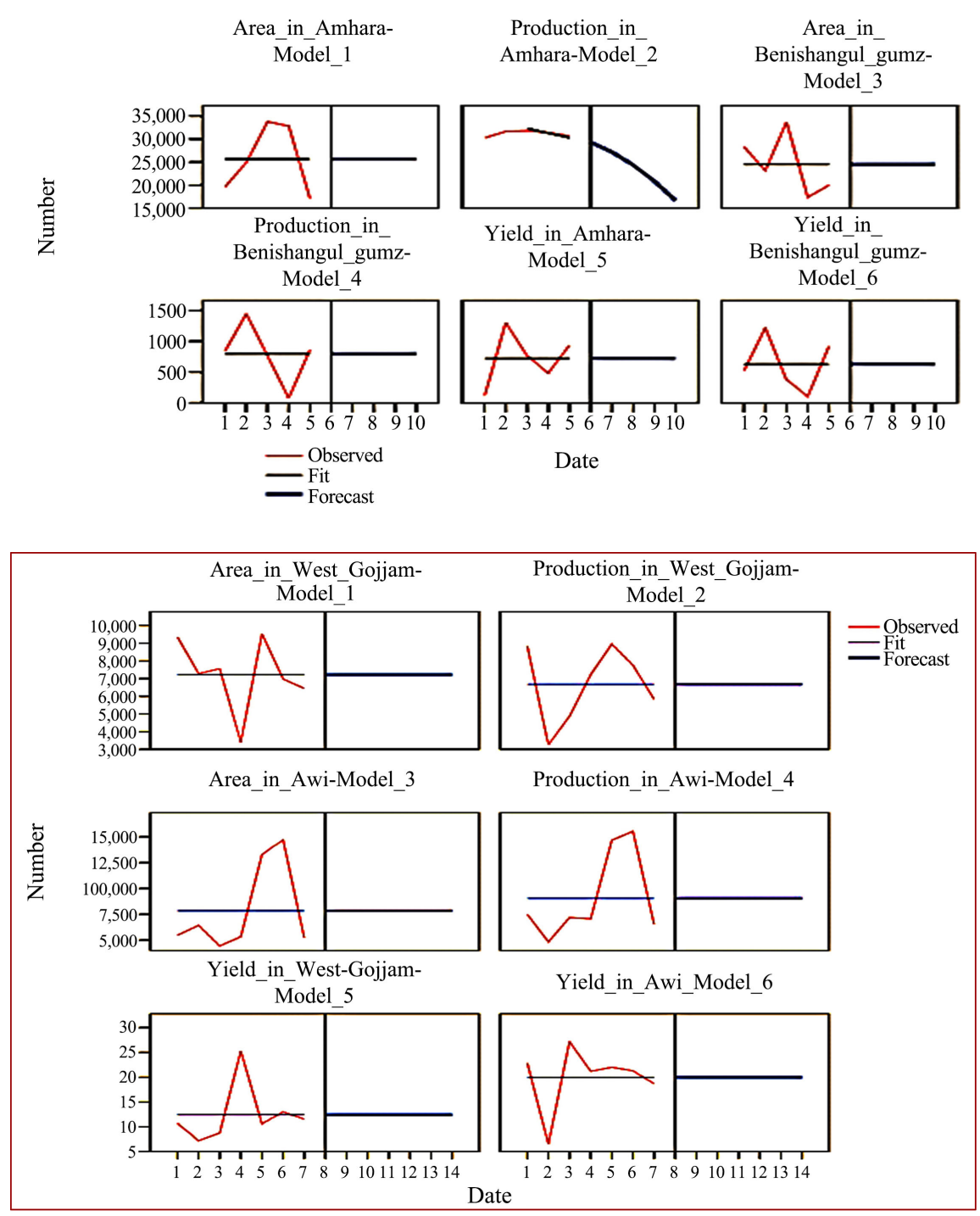

Figure 14. Future trends of Lupin coverage and production.

2017/18 cropping seasons. This indicated that the ratio of utilization showed inconsistent trends. Therefore, 1) breeding low alkaloid content, high disease resistant and high yield varieties, 2) creating visual aware about the nutrient value, 3) government and agricultural extension workers must be give prior attention, 4) maximizing the marketing value chains of the crop, which is the only instrument maximizing the productivity and its utilization as household consumption.

\section{Acknowledgements}

The authors greatly appreciate the CSA and FAOSTAT to their published information. We would like to thank Mr. Mulugeta Fiseha for his arc map.

\section{Conflicts of Interest}

The authors declare no conflicts of interest regarding the publication of this paper. 


\section{References}

[1] Atnaf, M., Kassahun, T., Kifle, D. and Dagne, W. (2015) Extent and Pattern of Genetic Diversity in Ethiopian White Lupin Landraces for Agronomical and Phenological Traits. African Crop Science Journal, 23, 327-341. https://doi.org/10.4314/acsj.v23i4.3

[2] Azeze, H., Firew, M., Yigzaw, D., Zerihun, T. and Negussie, M. (2016) Challenges on Production and Utilization of White Lupin (Lupinus albus L.) in Ethiopia: A Strategic Orphan Crop. American Journal of Experimental Agriculture, 13, 1-14. https://doi.org/10.9734/AJEA/2016/27930

[3] Yeheyis, L., Kijora, C., Solomon, M., Anteneh, G. and Peters, K.J. (2010) White Lupin (Lupinus albus L.), the Neglected Multipurpose Crop: Its Production and Utilization in the Mixed Crop-Livestock Farming System of Ethiopia. Livestock Research for Rural Development, 22, Article No. 74.

[4] Ramanujam, R., Fiocchi, A. and Smith, W. (2016) Lupin Allergy: Is It Really a Cause for Concern? Agro Food Industry Hi-Tech, 27, 10-14.

[5] Oumer, A., Petros, Y., Tesfaye, K., Teshome, A. and Bekele, E. (2015) Inter Simple Sequence Repeat (ISSR) Analysis of Ethiopian White Lupine (Lupinus albus L.) African Journal of Biotechnology, 14, 1552-1563. https://doi.org/10.5897/AJB2014.14379

[6] Hane, J.K., Yao, M., Lars, G.K., Matthew, N.N., Gagan, G., Craig, A.A., Philipp, E.B., Armando, B., Scott, B., Steven, C., David, E., Rhonda, F., Gao, L.-L., Maria, J.H., Wei, H., Bhavna, H., Sean, L., Liu, C.-W., Annette, M.G., Grant, M., Jeremy, M., James, W., Jianbo, J. and Karam, B.S. (2017) A Comprehensive Draft Genome Sequence for Lupin (Lupines angustifolius), an Emerging Health Food: Insights into Plant Microbe Interactions and Legume Evolution. Plant Biotechnology Journal, 15, 318-330. https://doi.org/10.1111/pbi.12615

[7] Lucas, M.M., Stoddard, F.L., Annicchiarico, P., Frías, J., Martínez-Villaluenga, C., Sussmann, D., Duranti, M., Seger, A., Zander, P.M. and Pueyo, J.J. (2015) The Future of Lupin as a Protein Crop in Europe. Frontiers in Plant Science, 6, 705. https://doi.org/10.3389/fpls.2015.00705

[8] Teferra, B., Yeheyis, L., Nelson, M., Taylor, J., Mcnaughton, D., Sergeant, A. and Sanders, H. (2019) Farmers' Decisions and Determinants of Crop Rotations with Lupin: The Case of West Amhara Region, Ethiopia. Review of Agricultural and Applied Economics, 22, 24-31. https://doi.org/10.15414/raae.2019.22.01.24-31

[9] Tizazu, H. and Emire, S.A. (2010) Chemical Composition, Physicochemical and Functional Properties of Lupin (Lupinus Albus) Seeds Grown in Ethiopia. African Journal of Food, Agriculture, Nutrition and Development, 10, 3029. https://doi.org/10.4314/ajfand.v10i8.60895

[10] Central Statistical Agency (2004) Agricultural Sample Survey 2003/2004, Volume 1: Area and Production of Major Crops. Central Statistical Agency, Federal Democratic Republic of Ethiopia, Addis Ababa.

[11] Central Statistical Agency (2006) Agricultural Sample Survey 2005/2006, Volume 1: Area and Production of Major Crops. Central Statistical Agency, Federal Democratic Republic of Ethiopia, Addis Ababa.

[12] Central Statistical Agency (2007) Agricultural Sample Survey 2006/2007, Volume 1: Area and Production of Major Crops. Central Statistical Agency. Federal Democratic Republic of Ethiopia, Addis Ababa.

https://doi.org/10.5089/9781451812794.002

[13] Central Statistical Agency (2008) Agricultural Sample Survey 2007/2008, Volume 1: 
Area and Production of Major Crops. Central Statistical Agency, Federal Democratic Republic of Ethiopia, Addis Ababa.

https://doi.org/10.5089/9781451812824.002

[14] Central Statistical Agency (2009) Agricultural Sample Survey 2008/2009, Volume 1: Area and Production of Major Crops. Central Statistical Agency, Federal Democratic Republic of Ethiopia, Addis Ababa.

[15] Central Statistical Agency (2010) Agricultural Sample Survey 2009/2010, Volume 1: Area and Production of Major Crops. Central Statistical Agency, Federal Democratic Republic of Ethiopia, Addis Ababa.

[16] Central Statistical Agency (2011) Agricultural Sample Survey 2010/2011, Volume 1: Area and Production of Major Crops. Central Statistical Agency, Federal Democratic Republic of Ethiopia, Addis Ababa.

[17] Central Statistical Agency (2012) Agricultural Sample Survey 2011/2012, Volume 1: Area and Production of Major Crops. Central Statistical Agency, Federal Democratic Republic of Ethiopia, Addis Ababa.

[18] Central Statistical Agency (2013) Agricultural Sample Survey 2012/2013, Volume 1: Area and Production of Major Crops. Central Statistical Agency, Federal Democratic Republic of Ethiopia, Addis Ababa.

[19] Central Statistical Agency (2015) Agricultural Sample Survey 2014/2015, Volume 1: Area and Production of Major Crops. Central Statistical Agency, Federal Democratic Republic of Ethiopia, Addis Ababa.

[20] Central Statistical Agency (2016) Agricultural Sample Survey 2015/2016, Volume 1: Area and Production of Major Crops. Central Statistical Agency, Federal Democratic Republic of Ethiopia, Addis Ababa.

[21] Central Statistical Agency (2018) Agricultural Sample Survey 2017/18, Volume I. Production of Major Crops. Central Statistical Agency, Federal Democratic Republic of Ethiopia. Statistical Bulletin 584.

[22] Central Statistical Agency (2018) Agricultural Sample Survey 2017/2018, Volume II: Crop and Livestock Product Utilization. Central Statistical Agency, Federal Democratic Republic of Ethiopia.

[23] Biadge, K. and Esayas, A. (2018) Sweet Lupine Recipe and Nutritional Content of Recipe at Holeta, Ethiopia. The Academic Research Journal of Agricultural Science and Research, 6, 392-395. https://doi.org/10.17352/jfsnt.000014

[24] Hemavathi, M. and Prabakaran, K. (2018) ARIMA Model for Forecasting of Area, Production and Productivity of Rice and Its Growth Status in Thanjavur District of Tamil Nadu, India. International Journal of Current Microbiology and Applied Sciences, 7, 149-156. https://doi.org/10.20546/ijcmas.2018.702.019

[25] Logan, C. and Yeshtila, W.B. (2018) Average Crop Yield (2001-2017) in Ethiopia: Trends at National, Regional and Zonal Levels. Data in Brief, 16, 1025-1033. https://doi.org/10.1016/j.dib.2017.12.039

[26] Thami, A.I., Al Faiz, C., Papineau, J. and Huyghe, C. (2004) Collection of the Lupinus Genus in Morocco. In: Ferchichi, A. and Ferchichi, A., Eds., Réhabilitation des pâturages et des parcours en milieu méditerranéens, CIHEAM, Zaragoza, 47-49 (Cahiers Options Méditerranéennes, No. 62).

[27] Yeheyis, L., Kijora, C., van Santen, E. and Peters, K.J. (2012) Sweet Annual Lupins (Lupinus sp.); Their Adaptability and Productivity in Different Agro Ecological Zones of Ethiopia. Journal of Animal Science Advances, 2, 201-215.

[28] Atnaf, M., Yao, N., Martina, K., Dagne, K., Wegary, D. and Tesfaye, K. (2017) Mo- 
lecular Genetic Diversity and Population Structure of Ethiopian White Lupin Landraces: Implications for Breeding and Conservation. PLOS ONE, 12, e0188696. https://doi.org/10.1371/journal.pone.0188696 


\section{Appendix}

Table A1. Land coverage, production and yields of Lupin in some African Country (2001-2017).

\begin{tabular}{|c|c|c|c|c|c|c|c|c|c|c|c|c|}
\hline Year & $\begin{array}{c}\text { Area in } \\
\text { Egypt } \\
\text { (ha) }\end{array}$ & $\begin{array}{l}\text { Production } \\
\text { (q) in } \\
\text { Egypt }\end{array}$ & $\begin{array}{c}\text { Area in } \\
\text { Morocco }\end{array}$ & $\begin{array}{l}\text { Production } \\
\text { in morocco }\end{array}$ & $\begin{array}{l}\text { Area in } \\
\text { South } \\
\text { Africa }\end{array}$ & $\begin{array}{c}\text { Production } \\
\text { in South } \\
\text { Africa }\end{array}$ & $\begin{array}{c}\text { Area in } \\
\text { Ethiopia } \\
\text { (ha) }\end{array}$ & $\begin{array}{l}\text { Production } \\
\text { (q)in } \\
\text { Ethiopia }\end{array}$ & $\begin{array}{l}\text { Yield } \\
\text { (q/ha) in } \\
\text { Egypt }\end{array}$ & $\begin{array}{c}\text { Yield } \\
(\mathrm{q} / \mathrm{ha}) \text { in } \\
\text { Morocoo }\end{array}$ & $\begin{array}{c}\text { Yield }(\mathrm{q} / \mathrm{ha}) \\
\text { in South } \\
\text { Africa }\end{array}$ & $\begin{array}{c}\text { Yield } \\
(\mathrm{q} / \mathrm{ha}) \text { in } \\
\text { Ethiopia }\end{array}$ \\
\hline 2001 & 2493 & 40,050 & 30,633 & 200,520 & 14,785 & 163,380 & 7252.36 & $59,713.78$ & 16.065 & 6.55 & 11.05 & 8.23 \\
\hline 2003 & 2413 & 39,440 & 39,812 & 259,540 & 10,100 & 40,400 & 15,016 & 48,326 & 16.35 & 6.52 & 4 & 3.22 \\
\hline 2005 & 1478 & 27,860 & 48,013 & 314,400 & 14,100 & 141,000 & 13,936 & 123,318 & 18.85 & 6.55 & 10 & 8.85 \\
\hline 2006 & 1500 & 28,000 & 52,105 & 341,830 & 16,000 & 144,000 & 25,526 & 287,173 & 18.67 & 6.56 & 9 & 11.25 \\
\hline 2007 & 1574 & 28,850 & 56,181 & 369,260 & 14,000 & 133,000 & $26,398.84$ & $165,541.58$ & 18.33 & 6.57 & 9.5 & 6.27 \\
\hline 2008 & 1302 & 23,840 & 60,243 & 396,690 & 12,518 & 120,440 & $20,469.4$ & $172,411.3$ & 18.31 & 6.59 & 9.62 & 8.42 \\
\hline 2009 & 1482 & 28,810 & 64,289 & 424,110 & 11,826 & 109,970 & $25,033.25$ & 416,759 & 19.44 & 6.6 & 9.3 & 16.65 \\
\hline 2010 & 1503 & 30,770 & 68,320 & 451,540 & 11,788 & 107,490 & $14,284.15$ & $196,154.18$ & 20.47 & 6.61 & 9.12 & 13.73 \\
\hline 2011 & 1531 & 31,670 & 72,336 & 478,970 & 11,741 & 108,350 & $34,229.45$ & $443,705.05$ & 20.68 & 6.62 & 9.23 & 12.96 \\
\hline 2012 & 764 & 15,510 & 76,338 & 506,400 & 11,746 & 109,680 & $33,170.03$ & $368,807.7$ & 20.3 & 6.63 & 9.34 & 11.12 \\
\hline 2014 & 546 & 9320 & 84,297 & 561,260 & 11,724 & 112,040 & $15,545.36$ & $176,905.8$ & 17.07 & 6.66 & 9.56 & 11.38 \\
\hline 2015 & 334 & 7250 & 88,254 & 588,690 & 11,579 & 111,930 & $16,788.2$ & $187,166.88$ & 21.73 & 6.67 & 9.67 & 11.15 \\
\hline 2016 & 208 & 3470 & 92,198 & 616,120 & 11,524 & 112,660 & $19,907.89$ & $274,066.82$ & 16.65 & 6.68 & 9.78 & 13.77 \\
\hline 2017 & 224 & 4200 & 96,126 & 643,550 & 11,484 & 113,530 & $17,877.23$ & $246,294.2$ & 18.75 & 6.7 & 9.89 & 13.78 \\
\hline
\end{tabular}

Sources: CSA [10]-[22].

Table A2. Lupin production in Ethiopia.

\begin{tabular}{cccc}
\hline year & Area harvested (ha) & Production (q) & Yield (q/ha) \\
\hline 2001 & 7252.36 & $59,713.78$ & 8.23 \\
2003 & $15,016.00$ & $48,326.00$ & 3.22 \\
2005 & $13,936.00$ & $123,318.00$ & 11.25 \\
2006 & 25,526 & 287,173 & 6.25 \\
2007 & $26,398.84$ & $165,541.58$ & 8.42 \\
2008 & $20,469.40$ & $172,411.30$ & 16.65 \\
2009 & $25,033.25$ & $416,759.00$ & 13.75 \\
2010 & $14,284.15$ & $196,154.18$ & 12.96 \\
2011 & $34,229.45$ & $443,705.05$ & 11.12 \\
2012 & $33,170.03$ & $368,807.70$ & 11.38 \\
2014 & $15,545.36$ & $176,905.80$ & 11.15 \\
2015 & $16,788.20$ & $187,166.88$ & 13.77 \\
2016 & $19,907.89$ & $274,066.82$ & 13.78 \\
\hline
\end{tabular}

Sources: CSA [10]-[22]. 
A. A. Habtemariam et al.

Table A3. Lupin production in Amhara and Benishangul gumz.

\begin{tabular}{ccccccc}
\hline Year & $\begin{array}{c}\text { Area harvested (ha) } \\
\text { in Amhara }\end{array}$ & $\begin{array}{c}\text { Production (q) in } \\
\text { Amhara }\end{array}$ & $\begin{array}{c}\text { Area harvested (ha) in } \\
\text { Benishangul gumz }\end{array}$ & $\begin{array}{c}\text { Production (q) in } \\
\text { Benishangul gumz }\end{array}$ & $\begin{array}{c}\text { yield (q/ha) in } \\
\text { Amhara }\end{array}$ & $\begin{array}{c}\text { Yield (q/ha) in } \\
\text { Benishangul gumz }\end{array}$ \\
\hline 2008 & $19,616.63$ & $171,554.65$ & 120 & 840 & 8.75 & 7 \\
2009 & $24,890.64$ & $415,310.94$ & 89 & 1,448 & 16.69 & 16.27 \\
2011 & $33,774.69$ & $442,832.66$ & 152.03 & 760 & 13.11 & 4.99 \\
2012 & $32,824.40$ & $368,645.35$ & 54.4 & 75.93 & 11.23 & 1.4 \\
2017 & $17,135.36$ & $244,558.66$ & 70.03 & 861.28 & 14.27 & 12.3 \\
\hline
\end{tabular}

Sources: CSA [10]-[22].

Table A4. Lupin production in West Gojjam and Awi zones.

\begin{tabular}{|c|c|c|c|c|c|c|}
\hline Year & $\begin{array}{c}\text { Area harvested (ha) } \\
\text { in West Gojjam }\end{array}$ & $\begin{array}{l}\text { Production (q) in } \\
\text { West gojjam }\end{array}$ & $\begin{array}{c}\text { Area harvested (ha) } \\
\text { in Awi }\end{array}$ & $\begin{array}{c}\text { Production (q) } \\
\text { in Awi }\end{array}$ & $\begin{array}{l}\text { Yield (q/ha) in } \\
\text { West Gojjam }\end{array}$ & $\begin{array}{c}\text { Yield ( } q / h a) \\
\text { in Awi }\end{array}$ \\
\hline 2006 & 9356.01 & $100,200.27$ & 5467.01 & $60,953.58$ & 10.71 & 11.15 \\
\hline 2007 & 7283.16 & $52,222.93$ & 6429.58 & $29,645.95$ & 7.17 & 4.61 \\
\hline 2008 & 7559.49 & $66,051.14$ & 4439.65 & $57,128.57$ & 8.74 & 12.87 \\
\hline 2010 & 3409.51 & $86,216.75$ & 5328.69 & $55,839.32$ & 25.29 & 10.48 \\
\hline 2011 & 9531.01 & $100,990.73$ & $13,295.71$ & $144,612.98$ & 10.6 & 10.8 \\
\hline 2012 & 6974.38 & $90,757.18$ & $14,720.99$ & $154,653.04$ & 13.01 & 10.51 \\
\hline 2015 & 6442.55 & $74,288.13$ & 5223.83 & $49,484.52$ & 11.53 & 9.47 \\
\hline
\end{tabular}

Sources: CSA [10]-[22].

Table A5. Lupin utilization in Percent.

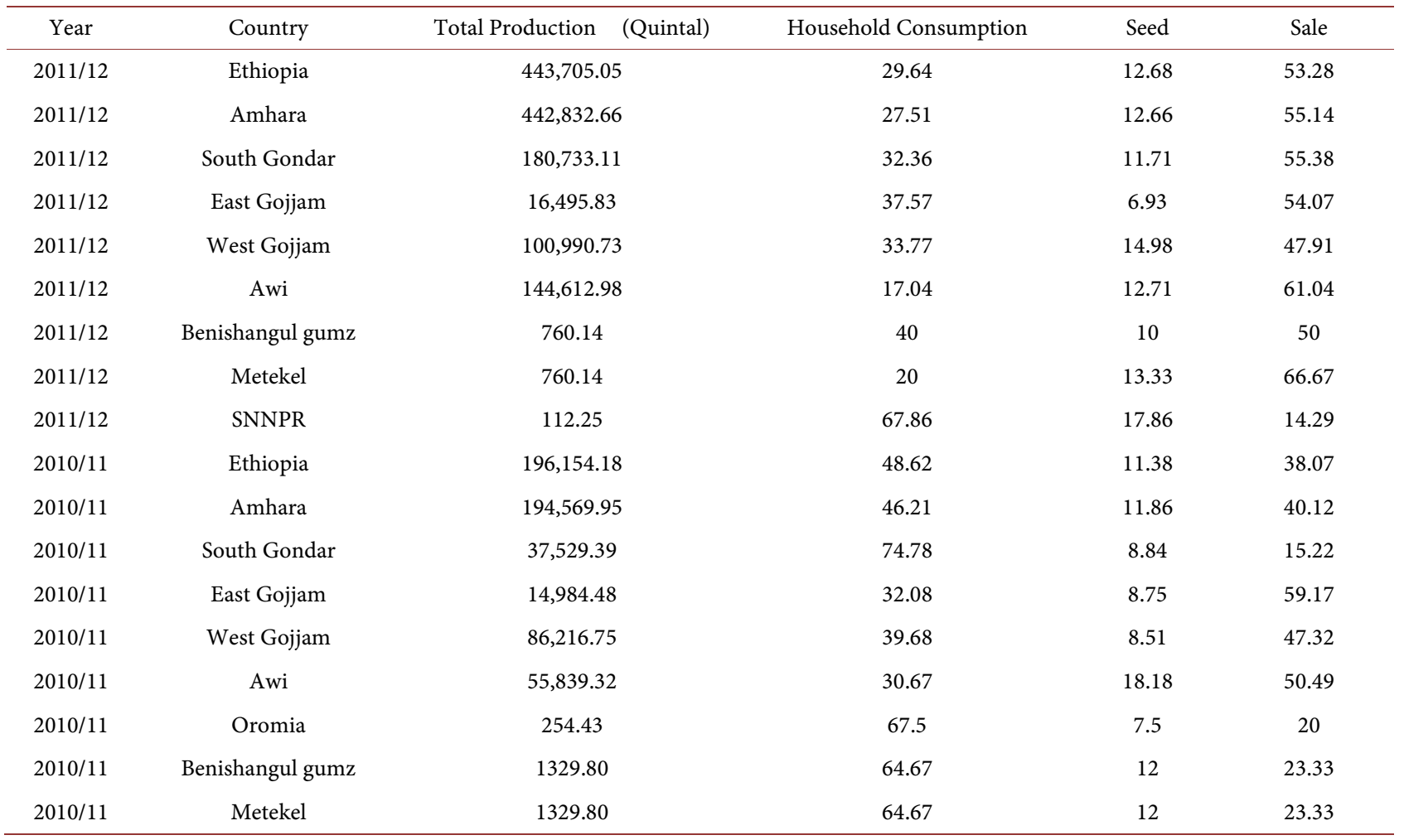

Sources: CSA [10]-[22]. 